$\overline{\text { REVIEW }}$ Bacteriology

\title{
Somatic Cells Count in Cow’s Bulk Tank Milk
}

\author{
Jan OLECHNOWICZ1)* and Jędrzej M. JAŚKOWSKI ${ }^{1)}$ \\ 1) Department of Veterinary Medicine, Faculty of Animal Breeding and Biology, Poznan University of Life Sciences, 52 Wojska \\ Polskiego, 60-625 Poznan, Poland
}

(Received 9 November 2011/Accepted 22 December 2011/Published online in J-STAGE 10 January 2012)

ABSTRACT. The objective of this study was therefore to present factors affecting somatic cell counts in bovine bulk milk as a result of intramammary infections as well as non-infectious factors. The paper presents also the impact of on-farm management practices on the level of bulk milk somatic cell counts and presents quality indicators in bulk tank milk. At the farm level bulk milk bacterial infection takes place through three main sources: bacterial contamination from the external surface of the udder and teats, from the surface of the milking equipment, and from mastitis microorganisms within the udder. The threshold of 200,000 cells $/ \mathrm{m} l$ identifies bacteriological negative quarters of the udder. The counts of mammary pathogens in bulk tank milk are relatively low, on average not exceeding 1,000 cfu $/ \mathrm{m} l$. Environmental pathogens predominate in bulk tank milk samples with somatic cells count $<300 \times 10^{3} / \mathrm{m} l$. KEY WORDS: bulk tank milk, microbiological quality, risk factor, somatic cell count.

doi: 10.1292/jvms.11-0506; J. Vet. Med. Sci. 74(6): 681-686, 2012

The causes of variation in somatic cells count (SCC) in cow's milk have been fairly well described. The biggest changes in the SCC are found in the case of the presence or absence of a bacterial infection within the mammary gland $[7,15,17,24,27,31,34,38]$. Other changes in the SCC, to a lesser extent, are caused by such factors as parity, stage of lactation, season, farm size, sampling interval, metabolic or physiological "stress", diurnal variability, very low or high cow body condition score (BCS), innate differences between quarters of the udder and cows, and technical error in measurement [3, 9, 10, 14, 18, 20, 35]. Each cow's milk is therefore characterised by a certain level of SCC. These are polymorphonuclear leukocytes (PMN), lymphocytes and macrophages. Macrophages are the main type of somatic cells from uninfected cows [19]. A dramatic increase in milk SCC occurs in the case of intramammary infection (IMI) $[19,29]$. This cell growth is a result of the transfer of white blood cells from the blood to the mammary gland [16]. At the same time the proportions between different types of somatic cells change significantly, with an increase in the PNM level (up to 90\%). The increase in milk SCC is related to changes in the milk composition. Several studies indicate a reduction in lactose, fat and casein contents in milk [16, 19]. These changes in milk are related to proteolysis, resulting in lower cheese yields and altered manufacturing properties $[33,42]$. The high level of lipolysis was observed in milk with a high percentage of PMN [8]. Bulk tank milk somatic cell counts (BTSCC) have three broad applications. They have been used to monitor

\footnotetext{
*Correspondence to: Olechnowicz, J., Department of Veterinary Medicine, Faculty of Animal Breeding and Biology, Poznan University of Life Sciences, 52 Wojska Polskiego, 60625 Poznan, Poland.

e-mail: olejanko@up.poznan.pl

(C)2012 The Japanese Society of Veterinary Science
}

the prevalence of mastitis in dairy herds, as indicators of raw milk quality and as more general indicators of hygienic conditions of milk production on farms [7, 15, 17, 21, 32, 34]. The correlations between BTSCC and total bacterial count (TBC) indicate a greater number of cells in smaller quantities of supplied bulk milk [41]. At the farm level, microbial contamination of bulk tank milk (BTM) occurs via 3 main sources, i.e., bacterial contamination from the external surface of the udder and teats, from the surface of the milking equipment, and from mastitis organisms from within the udder [27]. The reduction in SCC will, on average, be associated with reduced bulk tank TBC [1]. The levels and types of microorganisms in BTM provide information on the hygienic conditions during various steps of milk production on the farm. A number of microbiological count methods are used to monitor the hygienic quality of raw milk, including total aerobic count (TAC), which is an alternative to the standard plate count (SPC), preliminary incubation count (PIC), laboratory pasteurization count (LPC), coliform count (CC), and speciation of bulk tank milk for mastitis-causing microorganisms $[6,15]$. Various bacteria (TAC, PIC, LPC and CC) are important as indicators of on-farm hygienic conditions during milk production [7]. Milking machine wash failures are strongly associated with $\mathrm{CC}$, which suggests that proper cleaning of milking equipment plays a fundamental role in minimizing BTM contamination with coliforms [27]. Caring about food safety for Europeans, the ECC directive 92/46 (1992) stated that milk with SCC over 400,000 cells per $\mathrm{m} l$ cannot be used for human consumption, while limits are 750,000 in the U.S.A. and 500,000 in Canada [34].

\section{THE SOMATIC CELL COUNT IN BULK TANK MILK AS A RESULT OF INTRAMMARY INFECTIONS}

On modern cow farms coagulase-negative Staphylo- 
cocci (CNS) are the most common pathogens related to new IMI that are not present at dry-off, but are isolated from samples collected in the post-calving sampling period [24]. A majority of chronic IMI cases across the dry period are not caused by the same pathogen. Hence, the quarters and cows with $\mathrm{SCC} \geq 200,000$ cells $/ \mathrm{m} l$ across the dry period have a greater risk infection by major pathogens at the first dairy herd improvement (DHI) test and produce less milk when compared with quarters and cows with SCC $<200,000$ across the dry period. According to the authors cited [24], the SCC threshold of 200,000 cells $/ \mathrm{m} l$ identified bacteriologically negative quarters and cows with a margin of error of less than quarters of the udder and cows with IMI, in herds with a very low prevalence of infection and a high percentage of subclinical mastitis caused by CNS. In another study the same team of authors stated that quarters with $\mathrm{SCC} \geq 200,000$ cells $/ \mathrm{m} l$ across the dry period identified as a chronic infection based on SCC had an increased risk of developing clinical mastitis between 2 and 120 days in milking (DIM) when compared with quarters of the udder with $\mathrm{SCC}<200,000$ cells $/ \mathrm{m} l$ estimated as uninfected in the dry period [25]. Parity and the occurrence of clinical mastitis in previous lactations are also factors increasing the risk of clinical mastitis in the first 120 DIM. In terms of bacteriological monitoring considerable variability has been observed in bulk milk bacterial counts within farms and between farms [26]. Milk loads with CC and LPC are more likely to increase than that of TBC. A seasonal effect on TBC, CC, and LPC and milk temperature was found to vary significantly between farms. Changes of BTSCC in BTM are reflected in CNS count and the frequency of isolation of Staphylococcus aureus (SA) and Streptococcus agalactiae (SAG) from BTM [15]. Low correlations were observed between bacterial counts. Ryšánek and Babák [30] found that associations between values of BTSCS and $\log$ BTTBC (bulk tank total bacterial count) or log BTCBC (bulk tank coliform bacteria count) resulted in low, but statistically significant correlations. The level of BTSCC and bacterial counts in BTM depend on the use and application of automatic milking, teat dipping practices, pre- and postmilking teat disinfection procedures as well as bedding type. The correlations between the prevalence of high somatic cell counts (SCC $>250,000$ cells $/ \mathrm{ml}$; subclinical mastitis situation in the herd) and BMSCC, yield-corrected test-day SCC, and the arithmetic average test-day SCC (HSCC) were 0.64, 0.78 , and 0.89 , respectively [17]. On this basis it may be concluded that HSCC is a more appropriate parameter than BMSCC when determining the average herd subclinical mastitis situation in a dairy herd. Characteristics of the trend for SCC movement across a threshold of 200,000 cells $/ \mathrm{m} l$ between consecutive milk recordings for large samples of milk recording in England and Wales indicate that between herds an extensive variation is observed in the proportion of cows undergoing different transition [21]. It is possible to identify specific SCC patterns, which would be helpful in identifying mastitis in dairy cows; however, only $10 \%$ of the herds in terms of SCC transition patterns may be used as targets and benchmarks when evaluating mastitis. The number of somatic cells from single samples may not be considered a method to separate quarters indicated as uninfected and infected for Gyr cows, because the sensitivity and specificity of SCC in terms of the studied thresholds are very low [22]. The occurrence of IMI and the bacterial species are the main factors responsible for SCC variation in mammary quarters of Gyr cows. In a study conducted on this cow breed samples infected by major pathogens in milk had higher SCCs when compared with SCC levels in samples infected by minor pathogens. Counts for mammary pathogens in BMT were relatively low, on average not exceeding $1,000 \mathrm{cfu} / \mathrm{m} l$ [31]. Environmental pathogens predominated in BTM samples with $\mathrm{SCC}<300 \times 10^{3} / \mathrm{m} l$, and contagious mastitis pathogens predominated in BTM samples with $\mathrm{SCC}>300 \times 10^{3} / \mathrm{m} l$. No significant correlation was found between bacterial counts of different pathogens and BTSCC. In contrast, some correlation was recorded with counts of microorganisms in BTM in four selective culture media; however, the applied selective culture media were not very effective in monitoring mastitis rates in dairy herds according to the model proposed by the authors [38]. Under the conditions of this experiment, mastitis occurrence showed few correlations with counts of microorganisms in bulk raw milk in four selective culture media. Samples of milk from each quarter of the udder were analyzed to detect possible mastitis using the Tamis Test. All of the positive samples were divided into Tamis 1, Tamis 2, and Tamis 3 according to the intensity of clots in the milk. Two counts of microorganisms were negatively correlated with cases of Tamis 3 and no-bacterial-growth mastitis, while two counts of microorganisms were positively correlated with the occurrence of coagulase-positive staphylococci. Two selective culture media used for Staphylococcus sp. count (BairdParker Agar and Blood Agar plus potassium tellurite) were effective in identifying mastitis rates with coagulase-positive staphylococci in dairy herds. In clinical cases of mastitis Staph. aureus was a common microorganism isolated from milk samples. In cows after calving, in the middle of lactation and before the dry period CNS were isolated from milk samples. Corynebacterium spp. were also commonly isolated in all sample series besides clinical mastitis. Klebsiella species, Streptococcus uberis, Streptococcus dysgalactiae, Staphylococcus hyicus, Streptococcus canis, Enterobacter, Nocardia, Prototheca, Arcanobacterium pyogenes, yeasts, and fungi were also cultured, although less frequently [28]. The relative proportion of lymphocyte and PMN changed with the total BMSCC. Cells in the overriding BMSCC were lymphocytes, but for milk PMN dominated with more than $3,000 \times 10^{3}$ cells $/ \mathrm{m} l$. In milk with the highest proportion of PMN higher activities of antioxidant enzymes were observed. During the inflammation of mammary glands the PMN cells produce reactive oxygen metabolites. The high level of SCC/PMN causes an increase of catalase and glutathione peroxidase (GSHPx) activities in the mammary glands, indicating that biological membranes were attacked by free radicals [11]. Higher somatic cell counts resulted in higher malondialdehyde (MDA) concentrations in raw cows' milk [39]. Hence, it seems that oxidative stress is as- 
sociated with an inflammation of udder quarters. Elevated PMN levels in bulk milk indicate an increased prevalence of mastitis [16]. A high level of PMN in bulk milk may be related to implications for quality of dairy products.

\section{MANAGEMENT PRACTICES AND SOMATIC CELL COUNT IN BULK TANK MILK}

Among the many management practices in dairy herds, only a few are directly related to the number of somatic cells in milk [4]. However, it must be taken into account that many management practices in mastitis control programs are primarily to prevent the clinical forms of mastitis, and not a high number of somatic cells in bulk milk. These are important management practices that are associated with udder health in cows. Both total aerobic and preliminary incubation counts are positively correlated with the level of teat contamination before milking preparation of udders, manual cleaning of the bulk tank, and the type of detergent used [5]. Various methods of premilking udder preparation are also of importance and the use of pre-teat dip after drying is associated with reducing the bacterial counts. Failure to examine the udder before milking is associated with higher BTSCC. A study conducted in Chile showed that almost all farmers in that country (98\%) practiced post-milking teat disinfection (PMTD) in their herds. PMTD reduced BTSCC and was positively associated with individual-cow somatic cell count (ICSCC) and fore milking [40]. In relation to the milking procedure milkers should wear gloves during milking, and apply after milking teat disinfection. Cows with high somatic cell counts and clinical mastitis should be milked last, and the milking unit for these cows should be cleaned and disinfected after each milking. The milking parlor should be kept clean and at least once a year the milking system has to be controlled [4]. After milking cows should be standing, as many authors points out that it is associated with low somatic cell counts, and the desirability of such practices was especially indicated by the findings of Lievaart et al. [17]. The application of an intramammary antibiotic treatment during the dry period is not consistently associated with lower somatic cell counts in milk $[2,4]$. However, daily inspection of udders in dry cows to detect mastitis during the dry period is also consistently associated with lower SCC. Similarly, the use of the California Mastitis Test (CMT) is related to a low number of somatic cells. Also, frequent clipping of udder hairs and parenteral selenium supplementation are consistently associated with lower herd SCCs. Several studies indicate an association of the dietary component with herd-level SCC [4, 12, 36, 37]. Shortage of $\alpha$-tocopherol and selenium in the diet of cows leads to impaired PMN activity. Dietary supplementation of cows with selenium and $\alpha$-tocopherol leads to a rapid influx of PMN to intramammary bacteria and their killing [37], as well as lowering the frequency and shortening the duration of clinical mastitis [36]. During the dry period cows supplemented with 740 IU of $\alpha$-tocopherol had a $37 \%$ lower incidence of clinical mastitis in the following lactations when compared to cows fed ad libitum with haylage, providing an estimated
320 IU $\alpha$-tocopherol per cow per day in this period. Injection of $0.1 \mathrm{mg}$ selenium/ $\mathrm{kg}$ body weight 21 days before calving had no effect on the incidence of clinical mastitis [36]. According to these authors, clinical symptoms were observed over a shorter period of time in cows supplemented with both $\alpha$-tocopherol and selenium than in cows supplemented with either micronutrient alone (44 and 46\%, respectively). An improved cow udder health status was found in Swedish organic herds when compared to the conventional ones, and the main difference in the management of these herds is connected with the intensity of feeding (proportions of concentrates fed), whereas the relationship between udder health and the intensity of feeding in cows requires further research [12]. In Great Britain no difference was found in SCC between organic and nonorganic dairy cows on 80 farms, and many of the management practices affecting SCC may be used by farmers [13]. It is not only the effect of the organic status, but also there was no impact of housing type (straw vs. free-stalls) on SCC. Improvement of the SCC and udder health in cows in organic herds before and after the dry period may be provided through the identification of cows with subclinical mastitis assessed with the use of monthly herd tests (CMT), assuming the threshold of 150,000 or 200,000 cells $/ \mathrm{m} l$. Secondly, before the dry period monitoring of udder health and if necessary the administered treatment, and thirdly, drying-off procedures and the continued monitoring of the udder health during the dry period have to be carried out with the proper hygienic standard [23]. Udder quarters with $\mathrm{SCC} \geq 200,000$ cells $/ \mathrm{m} l$ across the dry period increase the risk of clinical mastitis between 2 and 120 DIM when compared with quarters with $\mathrm{SCC}<200,000$ cells $/ \mathrm{m} l$ [25]. According to those authors, parity and the occurrence of mastitis in a previous lactation are also risk factors for the development of clinical mastitis in the first 120 DIM. In the above mentioned study the following management practices and technological factors reduced the level of SCC: the dry period planned to last 7-8 weeks, visual appraisal of foremilk, pre-milking udder massage, individual feed rationing, and the application of $\mathrm{MgO}$ and b-carotene additives to the feed ration [35].

\section{INDIVIDUAL COW FACTORS AND NON-INFECTIOUS FACTORS AFFECTING SOMATIC CELL COUNT IN BULK TANK MILK}

Individual cow factors are associated with an increased or decreased risk of SCC $>199,000 \mathrm{cell} / \mathrm{m} l$ at the next milk recording during lactation [3]. The results of the study conducted by these authors suggest an association between cows' BCS and SCC $>199,000$ cells $/ \mathrm{m} l$. Cows scored as $\mathrm{BCS}<1.5$ or $>3.5$ are significantly more likely to have an SCC $>199,000$ cells $/ \mathrm{m} l$ at the next milk recording. Teat-end callosity (TEC) is associated with a significantly decreased risk for SCC $>199,000$ cells $/ \mathrm{m} l$ at the next milk recording compared with a normal teat end status. Independent variables affecting the risk of increased SCC $>199,000$ cells $/ \mathrm{m} l$ include previous test-day SCC, parity of the cow, and the month of lactation $[3,10,13]$. Heifers are less likely to suc- 
cumb to a previous case of mastitis and are unlikely to be persistently infected and recorded as having a elevated SCC at subsequent milk recordings [3]. Many authors point to the seasonal variation of bulk milk somatic cell counts $[9,13$, $20,35]$. In 33 dairy herds analyzed the number of somatic cells increased in milk during the summer, and the reason for this was a greater proportion of cows with SCC above 200,000 cells $/ \mathrm{m} l$ in the next two months. The somatic cells from these cows were responsible for a $70.8 \%$ increase in the total somatic cells produced between May and September when compared with October and March. There was no evidence that the increased number of new infections during the summer plays a role in the growth of SCC in bulk milk [9]. Similarly, SCC was highest in the summer period (June to August) in a study by Haskell et al. [13]. Those authors concluded that somatic cell counts increased with lactation number and varied with the stage of lactation, but were not affected by age at first calving. Somatic cell count was also associated with the individual cow's milk yield for that lactation, with higher-yielding cows having lower cell counts. In another study production of the herd and season of the year were significantly associated with BTSCC [20]. The results of observations conducted in Polish family farms indicate that in the period from July to September the SCC in bulk tank milk was higher than in the other months [35]. In herds of more than 15 cows higher levels of SCC were found than in smaller herds. In an American study similar relationships were found between small and large Wisconsin farms, as generally milk from small farms is of higher quality than milk from large farms. However, this has not been scientifically proven, at least when SPC and SCC are used as the quality indicators and the farm size categorizations [14]. Improved environment and cows' hygiene standards before milking and during milking are the main factors associated with BMSCC $\leq 200,000$ cells $/ \mathrm{m} l$ [40]. For the reliability of BTSCC results the milk samples should be tested on different data sets from different countries with different sampling intervals [18]. No effect of variability (measured by SD) in the accuracy of the results was found for different sampling BTSCC intervals.

\section{QUALITY INDICATORS IN BULK TANK MILK}

The high quality of pasteurized milk and dairy products is mainly provided thanks to high quality raw milk. Production of milk with low bacterial counts on the farm depends on management practices [5]. The dominant mammary pathogens found by SPC were largely environmental pathogens [31]. Their source may be environmental, rather than from an infected mammary gland because no significant difference in BTSCC was found in comparison with pathogenfree samples of bulk tank milk (BTM). However, significant differences were found in BTSCC between BTM samples containing Str. agalactiae, Staph. aureus and Str. dysgalactiae and BTM samples that were pathogen-free. Counts for mammary pathogens in BTM samples were relatively low, on average not exceeding $1,000 \mathrm{cfu} / \mathrm{ml}$. Bacterial and somatic cell counts are reference methods used as indicators of raw milk quality $[5,26]$. Somatic cells may also be used to measure the IMI and milk quality of cows, herd and population levels [34]. Bacteria commonly monitored in bulk milk show great variation. During milk production the indicators of hygienic conditions on the farm include TAC, PIC, LPC, and CC [5]. The season was a significant predictor for all bacterial counts with the lowest counts tending to occur in winter. Increased milk loads with CC and the LPC were associated with a high probability of TBC growth when compared with milk loads with small counts of CC and LPC [26]. The increase in TBC in milk causes an increase in SCC. Similarly, the increase in CC causes an increase in SCC, but laboratory pasteurization count is poorly associated with other indicators of quality milk. According to recent data the first relating polymorphonuclear leucocyte count (PMNC) in bulk tank milk can be used as an indicator of raw milk quality [43]. The study showed a strong correlation between PMNC and BTSCC in BTM; however, this correlation concerned total SCC and milk quality. The authors did not find a significant correlation between milk quality of one individual cell type and concluded that results do not support a hypothesis that PMNC would be a better indicator of BTM quality than SCC. Wickström et al. [44] concluded that $\alpha$ lactoalbumin ( $\alpha$-LA) is not a suitable marker of inflammation in bulk milk; however, it was significantly related with several milk components, such as lactose, $\beta$ lactoglobulin $(\beta-\mathrm{LG})$, and several individual caseins. However, this may have no practical significance, because $\alpha$-LA was not related to contents of total protein and casein. The proposed acute phase index (API) consisting of $\alpha$-LA, haptoglobulin (Hp), and serum amyloid A (SAA) was related to lactose content and casein number; however, it is not a sensitive marker for BM quality. SCC has been related to several milk traits such as casein content (contents of total casein; g/100 ml), casein number (several individual caseins, e.g., $\alpha \mathrm{S} 1$-casein, $\alpha \mathrm{S} 2-$ casein and $\beta$-casein) and proteolysis, although the practical importance of this indicator may be questioned.

\section{CONCLUSION}

At the farm level bulk milk bacterial infection takes place through three main sources: bacterial contamination from the external surface of the udder and teats, from the surface of the milking equipment, and from mastitis microorganisms within the udder. The threshold of 200,000 cells $/ \mathrm{ml}$ identifies bacteriological negative quarters of the udder. The quarters with $\mathrm{SCC} \geq 200,000$ cells $/ \mathrm{m} l$ across the dry period have an increased risk of developing clinical mastitits in the first four months of lactation. The arithmetic average test-day SCC (HSCC) is a more appropriate parameter than BMSCC to determine the average herd subclinical mastitis situation in dairy herds. The counts of mammary pathogens in BTM are relatively low, on average not exceeding 1,000 $\mathrm{cfu} / \mathrm{ml}$. Environmental pathogens predominate in BTM samples with $\mathrm{SCC}<300 \times 10^{3} / \mathrm{m} l$. The recent studies focus on qualitative indicators for BTM, but so far it seems that the somatic cells are the optimal indicator of milk quality and cow health status of the udder. 


\section{REFERENCES}

1. Berry, D. P., O’Brien, B., O'Callaghan, E. J., Sullivan, K. O. and Meaney, W. J. 2006. Temporal trends in bulk tank somatic cell count and total bacterial count in Irish dairy herds during the past decade. J. Dairy Sci. 89: 4083-4093. [Medline] [CrossRef]

2. Bradley, A. J., Breen, J. E., Payne, B. and Green, M. J. 2011. A comparison of broad-spectrum and narrow-spectrum dry cow therapy used alone and in combination with a teat sealant. $J$. Dairy Sci. 94: 692-704. [Medline] [CrossRef]

3. Breen, J. E., Bradley, A. J. and Green, M. J. 2009. Quarter and cow risk factors associated with a somatic cell count greater than 199,000 cells per milliliter in United Kingdom dairy cows. J. Dairy Sci. 92: 3106-3115. [Medline] [CrossRef]

4. Dufour, S., Fréchette, A., Barkema, H. W., Mussell, A. and Scholl, D. T. 2011. Invited review: effect of udder health management practices on herd somatic cell count. J. Dairy Sci. 94: 563-579. [Medline] [CrossRef]

5. Elmoslemany, A. M., Keefe, G. P., Dohoo, I. R. and Dingwell, R. T. 2009. Microbiological quality of bulk tank raw milk in Prince Edward Island dairy herds. J. Dairy Sci. 92: 42394248. [Medline] [CrossRef]

6. Elmoslemany, A. M., Keefe, G. P., Dohoo, I. R. and Jayaro, B. M. 2009. Risk factors for bacteriological quality of bulk tank milk in Prince Edward Island dairy herds. Part 2: bacteria count-specific risk factors. J. Dairy Sci. 92: 2644-2652. [Medline] [CrossRef]

7. Elmoslemany, A. M., Keefe, G. P., Dohoo, I. R., Wichtel, J. J., Stryhn, H. and Dingwell, R. T. 2010. The association between bulk tank milk analysis for raw milk quality and on-farm management practices. Prev. Vet. Med. 95: 32-40. [Medline] [CrossRef]

8. Gargouri, A., Hamed, H. and ElFeki, A. 2008. Total and differential bulk cow milk somatic cell counts and their relation with lipolysis. Livest. Sci. 113: 274-279. [CrossRef]

9. Green, M. J., Bradley, A. J., Newton, H. and Browne, W. J. 2006. Seasonal variation of bulk milk somatic cell counts in UK dairy herds: investigations of the summer rise. Prev. Vet. Med. 74: 293-308. [Medline] [CrossRef]

10. Hagnestam-Nielsen, C., Emanuelson, U., Berglund, B. and Strandberg, E. 2009. Relationship between somatic cell count and milk yield in different stages of lactation. J. Dairy Sci. 92: 3124-3133. [Medline] [CrossRef]

11. Hamed, H., El Feki, A. and Gargouri, A. 2008. Total and differential bulk cow milk somatic cell counts and their relation with antioxidant factors. C. R. Biol. 331: 144-151. [Medline] [CrossRef]

12. Hamilton, C., Emanuelson, U., Forslund, K., Hansson, I. and Ekman, T. 2006. Mastitis and related management factors in certified organic dairy herds in Sweden. Acta Vet. Scand. 48: 11. [Medline] [CrossRef]

13. Haskell, M. J., Langford, F. M., Jack, M. C., Sherwood, L., Lawrence, A. B. and Rutherford, K. M. D. 2009. The effect of organic status and management practices on somatic cell counts on UK dairy farms. J. Dairy Sci. 92: 3775-3780. [Medline] [CrossRef]

14. Ingham, S. C., Hu, Y. and Ané, C. 2011. Comparison of bulktank standard plate count and somatic cell count for Wisconsin dairy farms in three size categories. J. Dairy Sci. 94: 42374241. [Medline] [CrossRef]

15. Jayarao, B. M., Pillai, S. R., Sawant, A. A., Wolfgang, D. R. and Hegde, N. V. 2004. Guidelines for monitoring bulk tank milk somatic cell and bacterial counts. J. Dairy Sci. 87: 35613573. [Medline] [CrossRef]

16. Kelly, A. L., Tiernan, D., O'Sullivan, C. and Joyce, P. 2000. Correlation between bovine milk somatic cell count and polymorphonuclear leukocyte level for samples of bulk milk and milk from individual cows. J. Dairy Sci. 83: 300-304. [Medline] [CrossRef]

17. Lievaart, J. J., Kremer, W. D. J. and Barkema, H. W. 2007. Short communication: comparison of bulk milk, yield-corrected, and average somatic cell counts as parameters to summarize the subclinical mastitis situation in dairy herd. J. Dairy Sci. 90: 4145-4148. [Medline] [CrossRef]

18. Lievaart, J. J., Reneau, J. K., Kremer, W. D. J. and Barkema, H. W. 2011. Short communication: influence of sampling interval on the accuracy of predicting bulk milk somatic cell count. $J$. Dairy Sci. 94: 804-807. [Medline] [CrossRef]

19. Lindmark-Månsson, H., Bränning, C., Aldén, G. and Paulsson, M. 2006. Relationship between somatic cell count, individual leukocyte populations and milk components in bovine udder quarter milk. Int. Dairy J. 16: 717-727. [CrossRef]

20. Lukas, J. M., Reneau, J. K. and Kinsel, M. L. 2008. Predicting somatic cell count standard violations based on herd's bulk tank somatic cell count. Part I: analyzing variation. J. Dairy Sci. 91: 427-432. [Medline] [CrossRef]

21. Madouasse, A., Huxley, J. N., Browne, W. J., Bradley, A. J. and Green, M. J. 2010. Somatic cell count dynamics in a large sample of dairy herds in England and Wales. Prev. Vet. Med. 96: 56-64. [Medline] [CrossRef]

22. Malek dos Reis, C. B., Barreiro, J. R., Moreno, J. F. G., Porcionato, M. A. F. and Santos, M. V. 2011. Evaluation of somatic cell count thresholds to detect subclinical mastitis in Gyr cows. J. Dairy Sci. 94: 4406-4412. [Medline] [CrossRef]

23. Müller, U. and Sauerwein, H. 2010. A comparison of somatic cell count between organic and conventional dairy cow herds in West Germany stressing dry period related changes. Livest. Sci. 127: 30-37. [CrossRef]

24. Pantoja, J. C. F., Hulland, C. and Ruegg, P. L. 2009. Dynamics of somatic cell counts and intramammary infections across the dry period. Prev. Vet. Med. 90: 43-54. [Medline] [CrossRef]

25. Pantoja, J. C. F., Hulland, C. and Ruegg, P. L. 2009. Somatic cell counts status across the dry period as a risk factor for the development of clinical mastitis in the subsequent lactation. $J$. Dairy Sci. 92: 139-148. [Medline] [CrossRef]

26. Pantoja, J. C. F., Reinemann, D. J. and Ruegg, P. L. 2011. Factors associated with coliform count in unpasteurized bulk milk. J. Dairy Sci. 94: 2680-2691. [Medline] [CrossRef]

27. Pantoja, J. C. F., Reinemann, D. J. and Ruegg, P. L. 2009. Associations among milk quality indicators in raw bulk milk. $J$. Dairy Sci. 92: 4978-4987. [Medline] [CrossRef]

28. Reyher, K. K., Dufor, S., Barkema, H. W., Des Côteaux, L., DeVries, T. J., Dohoo, I. R., Keefe, G. P., Roy, J. P. and Scholl, D. T. 2011. The national cohort of dairy farms - a data collection platform for mastitis research in Canada. J. Dairy Sci. 94: 1616-1626. [Medline] [CrossRef]

29. Ryšánek, D. and Babák, V. 2005. Bulk tank milk somatic cell count as an indicator of the hygiene status of primary milk production. J. Dairy Res. 72: 400-405. [Medline] [CrossRef]

30. Ryšánek, D., Babák, V., Sládek, Z. and Toman, M. 2001. Variations among inbred heifers in the activities of polymorphonuclear leucocytes from the mammary gland and blood. J. Vet. Med. B 48: 31-41. [CrossRef]

31. Ryšánek, D., Zouharova, M. and Babák, V. 2009. Monitoring major mastitis pathogens at the population level based on ex- 
amination of bulk tank milk samples. J. Dairy Res. 76: 117123. [Medline] [CrossRef]

32. Sant'Anna, A. C. and Paranhos da Costa, M. J. R. 2011. The relationship between dairy cow hygiene and somatic cell count in milk. J. Dairy Sci. 94: 3835-3844. [Medline] [CrossRef]

33. Santos, M. V., Ma, Y. and Barbano, D. M. 2003. Effect of somatic cell count on proteolysis and lipolysis in pasteurized fluid milk during shelf-life storage. J. Dairy Sci. 86: 2491-2503. [Medline] [CrossRef]

34. Schukken, Y. H., Wilson, D. J., Welcome, F., Garrison-Tikofsky, L. and Gonzales, R. N. 2003. Monitoring udder health and milk quality using somatic cell counts. Vet. Res. 34: 579-596. [Medline] [CrossRef]

35. Skrzypek, R., Wójtowski, J. and Fahr, R. D. 2004. Factors affecting somatic cell count in cow bulk tank milk-a case study from Poland. J. Vet. Med. A Physiol. Pathol. Clin. Med. 51: 127-131. [Medline] [CrossRef]

36. Smith, K. L., Harrison, J. E., Hancock, D. D., Todhunter, D. A. and Conrad, H. R. 1984. Effect of vitamin E and selenium supplementation on incidence of clinical mastitis and duration of clinical symptoms. J. Dairy Sci. 67: 1293-1300. [Medline] [CrossRef]

37. Smith, K. L., Hogan, J. S. and Weiss, W. P. 1997. Dietary vitamin $\mathrm{E}$ and selenium affect mastitis and milk quality. J. Anim. Sci. 75: 1659-1665. [Medline]

38. Souto, L. I. M., Minagawa, C. Y., Telles, E. O., Garbuglio, M. A., Amaku, M., Melville, P. A., Dias, R. A., Sakata, S. T. and Benites, N. R. 2010. Correlation between mastitis occurrence and the count of microorganisms in bulk raw milk of bovine dairy herds in four selective culture media. J. Dairy Res. 77: 63-70. [Medline] [CrossRef]

39. Suriyasathaporn, W., Vinitketkumnuen, U., Chewonarin, T., Boonyayatra, S., Kreausukon, K. and Schukken, Y. H. 2006. Higher somatic cell counts resulted in higher malondialdehyde concentrations in raw cows' milk. Int. Dairy J. 16: 1088-1091. [CrossRef]

40. Tadich, N., Kruze, J., Locher, G. and Greek, L. E. 2003. Risk factors associated with BMSCC greater than 200,000 cells $/ \mathrm{m} l$ in dairy herds in southern Chile. Prev. Vet. Med. 58: 15-24. [Medline] [CrossRef]

41. van Schaik, G., Green, L. E., Guzmán, D., Esparza, H. and Tadich, N. 2005. Risk factors for bulk milk somatic cell counts and total bacterial counts in smallholder dairy farms in the 10th region of Chile. Prev. Vet. Med. 67: 1-17. [Medline] [CrossRef]

42. Velthuis, A. G. J. and van Asseldonk, M. A. P. M. 2011. Process audits versus product quality monitoring of bulk milk. $J$. Dairy Sci. 94: 235-249. [Medline] [CrossRef]

43. Wickström, E., Persson-Walter, K., Lindmark-Månsson, H. and Sternesjö, A. 2010. Short communication: relationships between $\alpha$-lactalalbumin and quality traits in bulk milk. $J$. Dairy Sci. 93: 4577-4581. [Medline] [CrossRef]

44. Wickström, E., Persson-Walter, K., Lindmark-Månsson, H., Östensson, K. and Sternesjö, Å. 2009. Relationship between somatic cell count, polymorphonuclear leucocyte count and quality parameters in bovine bulk tank milk. J. Dairy Res. 76: 195-201. [Medline] [CrossRef] 